\title{
A rational approach to COVID-19
}

\author{
Ruty Mehrian-Shai®
}

\begin{abstract}
It is crucial to use the wealth of information emerging from the ongoing SARS-CoV-2 pandemic and confront COVID-19 with a rational approach. There are proactive steps to prevent and fight COVID-19. Management of the disease should be according to clinical features and laboratory test markers and personalized therapeutic targets.
\end{abstract}

\section{Background}

Not applicable

\section{Main text}

In search for a rational approach to COVID-19, one should take into account the following 4 considerations: I. Risk factors, II. Clinical features III, Genomic and Stage markers, and IV. Treatment according to stage.

\section{Risk factors}

People without comorbidities should know that even healthy young people with coronavirus infection may succumb to acute respiratory distress syndrome because of the following risk factors: smoking, stress and depression, low physical activity, and high consumption of saturated fats, sugars, and refined carbohydrates [1]. In addition, underlying medical conditions in any age increase the risk for severe COVID-19 illness. According to the Centers for Disease Control and Prevention, the underlying medical conditions include cancer, chronic kidney disease, chronic obstructive pulmonary disease, heart conditions, immunocompromised state, type 2 diabetes mellitus, obesity (BMI $\geq 30 \mathrm{~kg} / \mathrm{m}^{2}$ ), pregnancy, and sickle cell disease.

\section{Clinical features}

Compared to non-severe pneumonia patients, the median age of severe patients is significantly older, and they are more likely to have chronic comorbidities [2]. Most

\footnotetext{
Correspondence: Ruty.shai@sheba.health.gov.il

Department of Pediatric Hemato-Oncology, Sheba Medical Center, Ramat Gan, Israel
}

common symptoms in severe patients are associated with, prolonged viral carriage in COVID-19. The symptoms are high fever, anorexia and dyspnea [3], taste and smell loss [4], and diarrhea [5].

\section{Genomics}

Personalized medicine will be enhanced by the integration of advances in human genomics into host big data of genetic determinants of susceptibility and the highly variable clinical manifestations. The host genome influences both innate and adaptive immunity. For example, a genome-wide association study for COVID-19 with respiratory failure detected a susceptibility locus at a chromosome $3 \mathrm{p} 21.31$ gene cluster and a potential involvement of the $\mathrm{ABO}$ blood-group system in COVID19 [6]. In this cluster, SLC6A20 encodes the sodiumamino acid (proline) transporter 1 (SIT1) which functionally interacts with angiotensin-converting enzyme 2, the SARS-CoV-2 cell-surface receptor [7]. Interestingly, proinflammatory cytokines interleukin (IL)-6 and tumor necrosis factor (TNF)-alpha stimulate the activity of amino acid transporter system A [8]. C-XC motif chemokine receptor 6 (CXCR6) regulates the location of lung-resident memory CD8 T cells [9]. CCR1 deficiency increases susceptibility to fatal coronavirus infection [10]. Associations of genes with severe disease were reported for apolipoprotein E, Toll-like receptor 7 , and IL-1 signaling pathway [11]. The most significant marker of poor prognosis and high mortality risk in patients with acute respiratory failure due to COVID-19 is vitamin $\mathrm{D}$ deficiency [12]. Vitamin $\mathrm{D}$ metabolism by vitamin $\mathrm{D}$ receptor (VDR) may exert its impact by

C The Author(s). 2020 Open Access This article is licensed under a Creative Commons Attribution 4.0 International License, which permits use, sharing, adaptation, distribution and reproduction in any medium or format, as long as you give appropriate credit to the original author(s) and the source, provide a link to the Creative Commons licence, and indicate if changes were made. The images or other third party material in this article are included in the article's Creative Commons licence, unless indicated otherwise in a credit line to the material. If material is not included in the article's Creative Commons licence and your intended use is not permitted by statutory regulation or exceeds the permitted use, you will need to obtain permission directly from the copyright holder. To view a copy of this licence, visit http://creativecommons.org/licenses/by/4.0/ The Creative Commons Public Domain Dedication waiver (http://creativecommons.org/publicdomain/zero/1.0/) applies to the data made available in this article, unless otherwise stated in a credit line to the data. 
modulating the innate and adaptive immune responses and suppression of the inflammatory process [13]. Analysis of vitamin D binding protein polymorphisms revealed that vitamin $\mathrm{D}$ binding protein 1 carriers might be less susceptible to infection and mortality due to COVID-19 [14]. In addition, a positive significant correlation was found between mortality rates and the prevalence of DBP gene polymorphism (GT genotype) at rs7041 locus [15]. Thus, population genomics provides the technology and infrastructure for large-scale health initiatives that are vital in COVID-19 management and in the combat of the virus.

\section{Stage markers}

Patients with moderate symptoms can worsen quickly and hence become much more severely affected, resulting in a high mortality rate [16]. Markers for immune suppression and inflammation should be used to identify the patients that will develop to the severe stage. Lymphopenia is associated with disease severity [17]. White blood cells and neutrophil counts are higher in intensive care unit cases [18]. Neutrophil to lymphocyte ratio may be a good measure to assess the immune suppression [19]. Inflammatory cytokines, tumor necrosis factor and interleukin 6, are higher in the severe stage [20]. Ferritin, which is an inflammation marker, may become the easiest to check for poor prognostic marker and it is high in non-survivors [20]. Once inflammation and immune suppression are detected, proper medication and care may significantly reduce the mortality rate of severe patients.

\section{Treatment according to stage}

Immune-boosting compounds such as interferons [21] and antivirals such as remdesivir [16] are expected to be most beneficial early in disease, when viral replication is still ramping up. On the other hand, in the severe stage which is characterized by immune suppression (loss of $\mathrm{T}$ cells) and inflammation (cytokine storm and release inflammatory cytokines), anti-inflammatory intervention would be effective [22]. Particularly, since the nervous system damage caused by viral infection may be mediated by the immune system [22-24], activation of immune cells in the brain will cause chronic inflammation and brain damage, which may be the cause of death. Currently, the recommended treatment is according to the severity of the disease. According to the National Institutes of Health COVID-19 treatment, guidelines panel https://www.covid19treatmentguidelines.nih.gov/, no specific antiviral or immunomodulatory therapy is recommended for patients with COVID-19 who are not hospitalized or who are hospitalized with moderate disease but do not require supplemental oxygen. For hospitalized patients with COVID-19 who require supplemental oxygen, a combination of remdesivir plus dexamethasone or other alternative corticosteroids such as prednisone, methylprednisolone, or hydrocortisone is recommended.

\section{Proactive steps}

In addition to avoiding the exposure to the virus, there are many proactive steps to prevent and/or fight COVID-19. Maintaining a healthy lifestyle and diet is essential along with social distancing, frequent hand washing, etc. The World Health Organization recommends limiting salt (less than $5 \mathrm{~g}$ per day), sugar (less than $5 \%$ of total energy intake or $\sim 5$ teaspoons), and total fat intake (less than $30 \%$ of total energy intake, of which no more than $10 \%$ should come from saturated fat (WHO*). Good hydration with water and avoiding caffeinated, soft drinks, and alcohol as well as $150 \mathrm{~min}$ of moderate-intensity or $75 \mathrm{~min}$ of vigorous-intensity physical activity per week. Seven to $8 \mathrm{~h}$ of sleep is recommended for healthy internal systems. It is recommended to reduce screen time and consume foods containing or promoting the synthesis of melatonin at dinner (almonds, bananas, cherries, and oats) [25]. Healthy and balanced nutrition containing a high amount of minerals, antioxidants, and vitamins can boost immune function [26]. Immune boosting elements can be consumed by sweet potatoes, carrots, and green leafy vegetables (beta carotene) red peppers, oranges, strawberries, broccoli, mangoes, lemons (vitamins C), nuts, seeds, spinach, and broccoli (vitamin E). Vitamin D is important for the healthy respiratory tract, decreasing the production of proinflammatory cytokines. Vitamin D can be gained during sun exposure or food consumption (fish, liver, eggs). Zinc from poultry, red meat, nuts, pumpkin seeds, sesame seeds, beans, and lentils will enhance immunity and inhibit virus proliferation. Food supplements to boost the immune system and reduce inflammation include curcumin, cinnamon, garlic, black pepper, selenium, lactoferrin, and quercetin [27]. Lactoferrin is a protein that is present in the milk exhibits antiviral activity, including against coronaviruses [28]. Selenium is abundantly found in common foods such as corn, garlic, onion, cabbage, and broccoli [27]. Quercetin is a polyphenolic compound, a type of flavonoid which is found in a variety of plants consumed by humans and available as a dietary supplement [29]. These recommendations are general prophylactic and therapeutic support measures. Recently, gut bacterial dysbiosis was linked to poor disease outcome and viral clearance [30]. It is possible to recruit the microbiome for maintenance, homeostasis, and recovery. Short-chain fatty acids (SCFAs) are the products of the fermentation of dietary fibers by the anaerobic intestinal microbiota in the gastrointestinal tract. SCFAs can reduce the luminal $\mathrm{pH}$, 
enhance the absorption of some nutrients, and reduce plasma glucose and cholesterol levels [31-33]. Consuming dietary fibers and enhancing bacteria population by probiotics consumption including Bifidobacteria, Lactobacillus Faecalibacterium prausnitzii, Eubacterium rectale, Bacteroidetes, and Firmicutes, Lachnospiraceae will regulate the $\mathrm{pH}$ of the gut, prevent leaky gut, and combat inflammation.

\section{Conclusions}

Personalized medicine and proactive steps to fight COVID-19 will reduce the severity of symptomatic individuals and the high fatality Toll of SARS-CoV-2.

\section{Acknowledgements}

Not applicable

\section{Author's contributions}

RMS drafted the manuscript. The authors read and approved the final manuscript.

\section{Authors' information}

Ruty Mehrian-Shai has extensive experience in genomics of complex diseases and healthcare.

\section{Funding}

Not applicable

\section{Availability of data and materials}

Not applicable

\section{Ethics approval and consent to participate}

Not applicable

\section{Consent for publication}

Not applicable

\section{Competing interests}

The authors declare that they have no competing interests.

Received: 27 October 2020 Accepted: 14 December 2020

Published online: 22 December 2020

\section{References}

1. Butler MJ, Barrientos RM. The impact of nutrition on COVID-19 susceptibility and long-term consequences. Brain Behav Immun. 2020;87:53-4. https://doi. org/10.1016/j.bbi.2020.04.040.

2. Yang $X$, et al. Clinical course and outcomes of critically ill patients with SARS-CoV-2 pneumonia in Wuhan, China: a single-centered, retrospective, observational study. Lancet Respir Med. 2020;8:475-81. https://doi.org/10. 1016/S2213-2600(20)30079-5.

3. Zhang G, et al. Clinical features and short-term outcomes of 221 patients with COVID-19 in Wuhan, China. J Clin Virol. 2020;127:104364. https://doi. org/10.1016/j.jcv.2020.104364.

4. Gautier JF, Ravussin Y. A new symptom of COVID-19: loss of taste and smell. Obesity (Silver Spring). 2020;28:848. https://doi.org/10.1002/oby.22809.

5. Wei XS, et al. Diarrhea is associated with prolonged symptoms and viral carriage in corona virus disease 2019. Clin Gastroenterol Hepatol. 2020;18: 1753-1759 e1752. https://doi.org/10.1016/j.cgh.2020.04.030.

6. Ellinghaus D, et al. Genomewide association study of severe COVID-19 with respiratory failure. N Engl J Med. 2020. https://doi.org/10.1056/ NEJMoa2020283.

7. Vuille-dit-Bille RN, et al. Human intestine luminal ACE2 and amino acid transporter expression increased by ACE-inhibitors. Amino Acids. 2015;47: 693-705. https://doi.org/10.1007/s00726-014-1889-6.

8. Jones HN, Jansson T, Powell TL. IL-6 stimulates system a amino acid transporter activity in trophoblast cells through STAT3 and increased expression of SNAT2. Am J Physiol Cell Physiol. 2009;297:C1228-35. https:// doi.org/10.1152/ajpcell.00195.2009.

9. Wein AN, et al. CXCR6 regulates localization of tissue-resident memory CD8 T cells to the airways. J Exp Med. 2019;216:2748-62. https://doi.org/10.1084/ jem.20181308.

10. Hickey MJ, et al. CCR1 deficiency increases susceptibility to fatal coronavirus infection of the central nervous system. Viral Immunol. 2007;20:599-608. https://doi.org/10.1089/vim.2007.0056.

11. Anastassopoulou C, Gkizarioti Z, Patrinos GP, Tsakris A. Human genetic factors associated with susceptibility to SARS-CoV-2 infection and COVID-19 disease severity. Hum Genomics. 2020;14:40. https://doi.org/10.1186/s40246020-00290-4.

12. Carpagnano GE, et al. Vitamin D deficiency as a predictor of poor prognosis in patients with acute respiratory failure due to COVID-19. J Endocrinol Investig. 2020. https://doi.org/10.1007/s40618-020-01370-x.

13. Malaguarnera L. Vitamin D3 as potential treatment adjuncts for COVID-19. Nutrients. 2020;12. https://doi.org/10.3390/nu12113512.

14. Speeckaert MM, De Buyzere ML, Delanghe JR. Vitamin D binding protein polymorphism and COVID-19. J Med Virol. 2020. https://doi.org/ 10.1002/jmv.26508.

15. Batur LK, Hekim N. The role of DBP gene polymorphisms in the prevalence of new coronavirus disease 2019 infection and mortality rate. J Med Virol. 2020. https://doi.org/10.1002/jmv.26409.

16. Wang $Y$, et al. Remdesivir in adults with severe COVID-19: a randomised, double-blind, placebo-controlled, multicentre trial. Lancet. 2020;395:156978. https://doi.org/10.1016/S0140-6736(20)31022-9.

17. Tan L, et al. Lymphopenia predicts disease severity of COVID-19: a descriptive and predictive study. Signal Transduct Target Ther. 2020;5:33. https://doi.org/10.1038/s41392-020-0148-4.

18. Huang C, et al. Clinical features of patients infected with 2019 novel coronavirus in Wuhan, China. Lancet. 2020;395:497-506. https://doi.org/10. 1016/S0140-6736(20)30183-5.

19. Yalon $M$, et al. Elevated NLR may be a feature of pediatric brain cancer patients. Front Oncol. 2019;9:327. https://doi.org/10.3389/fonc. 2019.00327.

20. Mehta P, et al. COVID-19: consider cytokine storm syndromes and immunosuppression. Lancet. 2020;395:1033-4. https://doi.org/10.1016/ S0140-6736(20)30628-0.

21. Zhou Q, et al. Interferon-alpha2b treatment for COVID-19. Front Immunol. 2020;11:1061. https://doi.org/10.3389/fimmu.2020.01061.

22. Li Y, Fu L, Gonzales DM, Lavi E. Coronavirus neurovirulence correlates with the ability of the virus to induce proinflammatory cytokine signals from astrocytes and microglia. J Virol. 2004;78:3398-406. https://doi.org/10.1128/ jvi.78.7.3398-3406.2004.

23. Klein RS, Garber C, Howard N. Infectious immunity in the central nervous system and brain function. Nat Immunol. 2017;18:132-41. https://doi.org/10. 1038/ni.3656.

24. Bohmwald K, Galvez NMS, Rios M, Kalergis AM. Neurologic alterations due to respiratory virus infections. Front Cell Neurosci. 2018;12:386. https://doi. org/10.3389/fncel.2018.00386

25. Meng $X$, et al. Dietary sources and bioactivities of melatonin. Nutrients. 2017;9. https://doi.org/10.3390/nu9040367.

26. Chandra RK. Effect of vitamin and trace-element supplementation on immune responses and infection in elderly subjects. Lancet. 1992;340:11247. https://doi.org/10.1016/0140-6736(92)93151-c.

27. Mrityunjaya $M$, et al. Immune-boosting, antioxidant and antiinflammatory food supplements targeting pathogenesis of COVID-19. Front Immunol. 2020;11:570122. https://doi.org/10.3389/fimmu.2020. 570122.

28. Wang Y, et al. Lactoferrin for the treatment of COVID-19 (review). Exp Ther Med. 2020;20:272. https://doi.org/10.3892/etm.2020.9402.

29. Aucoin $M$, et al. The effect of quercetin on the prevention or treatment of COVID-19 and other respiratory tract infections in humans: a rapid review. Adv Integr Med. 2020;7:247-51. https://doi.org/10.1016/j.aimed. 2020.07.007.

30. Zuo T, et al. Alterations in gut microbiota of patients with COVID-19 during time of hospitalization. Gastroenterology. 2020. https://doi.org/10.1053/j. gastro.2020.05.048

31. Macfarlane GT, Macfarlane S. Bacteria, colonic fermentation, and gastrointestinal health. J AOAC Int. 2012;95:50-60. https://doi.org/10.5740/ jaoacint.sge_macfarlane. 
32. Batterham RL, et al. Gut hormone PYY(3-36) physiologically inhibits food intake. Nature. 2002;418:650-4. https://doi.org/10.1038/ nature00887.

33. Todesco T, Rao AV, Bosello O, Jenkins DJ. Propionate lowers blood glucose and alters lipid metabolism in healthy subjects. Am J Clin Nutr. 1991;54:8605. https://doi.org/10.1093/ajcn/54.5.860.

\section{Publisher's Note}

Springer Nature remains neutral with regard to jurisdictional claims in published maps and institutional affiliations.

Ready to submit your research? Choose BMC and benefit from:

- fast, convenient online submission

- thorough peer review by experienced researchers in your field

- rapid publication on acceptance

- support for research data, including large and complex data types

- gold Open Access which fosters wider collaboration and increased citations

- maximum visibility for your research: over $100 \mathrm{M}$ website views per year

At BMC, research is always in progress.

Learn more biomedcentral.com/submissions 